\title{
Introduction
}

\author{
Angela Romano and Federico Romero
}

This book offers an unprecedented historical investigation into the strategies, expectations and predicaments of the European socialist regimes in the context of the opening up of a space for pan-European cooperation in the "long 1970s". It is the result of the five-year PanEur1970s research project, which has received funding from the European Research Council under the European Union's Horizon 2020 research and innovation programme (Grant Agreement no. 669194). The project brought together a team of historians with different yet complementary fields of specialisation. Their coordinated research has resulted in a re-conceptualisation of trans-European exchanges and cooperation against a background of Cold War constraints, global economic change and processes of regional integration. It sheds new light on the thinking and agency of the socialist regimes.

Over the last decade, Cold War historiography has revealed a complex pattern of intra-European détente embodied in a deepening web of contacts, interactions, exchanges and mutual obligations across the "Iron Curtain". ${ }^{1}$ Within this context, some historians of European integration have re-examined the emergence of the European Economic Community (EEC) as an influential international actor, particularly through the Conference on Security and Cooperation in Europe, and have appraised the EEC's reach and allure regarding the socialist countries. ${ }^{2}$

It is now evident that from the late 1960s, Europe's Cold War geopolitical and ideological divide cohabited with an emerging continental space for growing exchanges, trade and collaboration, which was often expected to foster convergence and interdependence. On the one hand, these trans-European connections offered the socialist countries much-needed patterns of exchange and potential regional integration. On the other hand, they opened up a less protected and self-enclosed environment that presented significant challenges to the stability, political control and ideological self-legitimisation of the regimes.

We explore these tensions by analysing the changing mindset of the European socialist elites, in particular their assumptions on the international division of labour and cooperation with Western Europe, their attempts at dealing with the commercial giant next door (i.e. the EEC) and the predicaments they faced when these strategies began to unravel. 


\section{State of the art and research questions}

Scholars of Russia and Eastern Europe and/or communism have brought to the fore the economic rationales for the socialist countries' policy of peaceful coexistence and cooperation with the West. By the mid-1960s, the rapid growth of their economies based on planning and intense industrialisation had reached its limits. As their economies could not adjust rapidly enough to the requirements of the unfolding technological revolution, the socialist governments recognised that foreign trade was an important factor in socialist growth and began to follow a long-term policy aimed at extending their trade with the developed market economies. ${ }^{3}$ Improved commercial relations with the West were expected to provide their enterprises with better access to Western technology and their citizens with a diversified range of consumer goods, thus enhancing socialist modernisation. Economic growth had become a conditio sine qua non for political stability in Eastern Europe since the late 1950s, as improving living standards appeared crucial for government legitimacy. Their importance grew even further after the suppression of the Prague Spring in 1968 wiped out the option of profound political reforms.

It is common knowledge that the socialist countries' strategies failed, sometimes in a spectacular way. We know that increased trade with the West did not bring the expected improvement in productivity and that the bloc's overall economic performance fell well short of Western capitalist achievements. Their attempts at opening up and reform turned out to be flawed, mostly amounting to an increasingly ineffective 'muddling through'. ${ }^{4}$ Trade with the global South did not balance increasing deficits with the West. Some tried to bridge the gap with foreign credits and eventually walked into a debt trap: Poland, Hungary, Bulgaria, the GDR. Romania would eventually repay its debts at the expense of depressing its domestic economy to unbearable levels. Czechoslovakia avoided indebtedness and just managed to stagnate. Ultimately, instead of a modernised socialism, these countries received a fatal 'kiss of debt'. 5 Therefore, the socialist governments 'faced two alternatives, either retreat to a conservative stagnation or proceed down the road of gradual capitalist restoration'. ${ }^{6}$ As Valerie Bunce put it, the choice had narrowed to two unpalatable options: liberalise and thereby destroy the system or put off reforms and purchase short-term stability but long-term doom. ${ }^{7}$ The apparent consolidation of the regimes by means of improved consumption turned out to be short-lived, while their public legitimacy was eroded by the unsustainable comparison with Western standards that increased East-West exchanges had put on full display. As the regimes' main claims to legitimacy - safety, full employment and rapid growth - were undermined, even the ruling elites lost their selfconfidence, opening the way for the 1989 collapse. $^{8}$

Our knowledge is now considerably richer than twenty or even ten years ago, yet important gaps still exist. To start with, most of the literature focuses on the domestic determinants of economic reforms, neglecting the impact of external factors, with the exception of those emanating from the Soviet Union. However, from the early 1970s Eastern Europe underwent a series of external economic 
shocks with serious repercussions on its stability. In several countries, this led to a second wave of (cautious) reforms under the pressure of deepening external imbalances. Several scholars have started to investigate the socialist countries' problematic relationship with globalisation and technological change, and their haphazard attempts at deepening relationships with world markets. ${ }^{9}$ Nevertheless, research on exogenous economic influences on transformations in the region is still in its infancy.

Even more glaring is the gap in our knowledge of the changing mindset and outlook of the European socialist elites, particularly their expectations in the evolving rapprochement with Western Europe and their reading of its integration process and its impact. The history of individual socialist countries' relations with the EEC during the Cold War has been largely overlooked or summarily dealt with under the rubric of their post-Cold War "return to Europe" in the context of EU enlargement. ${ }^{10}$ While a few historians have explored the Soviet Union's attitude and policy towards the EEC, studies on the other socialist countries' approaches to it are still scarce. ${ }^{11}$ This lack of historical analysis is startling. By the early 1970s, Yugoslavia was deeply dependent on economic and financial cooperation with the EEC. The EEC had also become the single largest importing and exporting market after the CMEA for the Central and Eastern European socialist countries. Therefore, the EEC's protectionist policies on agricultural products and quantitative restrictions on industrial goods affected the socialist economies to an important and growing extent. The EEC also affected the socialist regimes' attempts at integrating in the world economy, for example by asking them to pay an "admission ticket" to the GATT in commercial rather than political terms. The paucity of historiographical work on these matters is largely the result of the Cold War era legacy of separate studies on Eastern and Western Europe. So far, although historians working on the two sides of what used to be a divided Europe have had considerable contacts, they have usually operated with largely separate agendas and networks. In addition, the historiography on European integration has long developed in self-insulation within the geopolitical, institutional and conceptual boundaries of the Western European communities.

Our research specifically aimed to break down these traditional divides and to bring "Eastern" insights into the wider evolution of the European economies and institutions. It also crosses the traditional demarcations among diverse fields of historiography (namely the Cold War, contemporary Europe, communism, European integration and international economic history). We intertwine international, political and economic history perspectives in order to offer a dynamic portrait of the socialist elites' paradigms, constraints and goals in pursuing policies of cooperation with Western Europe and the EEC.

We assess the complex influence of European and global processes of transformation on the socialist elites' reading of the international political and economic environment and their consequent decisions. We then track the rise, inconsistencies and fall of the national expectations at the basis of their strategies. In so doing, we offer a scholarly analysis of pan-European cooperation that incorporates the 
socialist regimes' concepts and policies and is able to assess the development of the EEC from the (rather unhappy) perspective of these outsiders.

Our research has revolved around four main research questions:

- What were the European socialist regimes' expectations concerning EastWest trade and pan-European cooperation in the 1970s? Their views and analyses shaped the premises on which they assessed the desirability or necessity of opening up to international exchanges and prioritised specific policy goals. This appraisal was not only rooted in economic terms but was also strongly concerned with foreign policy issues. As Europe was morphing into a locus of potential rapprochement, recombination and convergence, most of the socialist countries viewed connections with Western Europe as levers for a cautious but determined reconfiguration of hierarchies within the socialist bloc. Soviet dominance could not be contested but deliberate attempts were made, and many more were conceived, at diluting it within a larger panEuropean web of contacts that enhanced each nation's own agency. In the case of Yugoslavia, closer relations with Western Europe had to be reconciled with the country's non-alignment policy.

- How did European socialist regimes assess the impact of the EEC on their economies and decide how to deal with it? We investigate their debates and policy solutions with specific attention to the complex interplay between national and CMEA options, and to the tensions between socialist integration and growing trans-European interdependence.

- Who in the political and economic elites advocated or opposed higher levels of East-West economic exchange? Party and government officials often had conflicting concerns about opening up to the West. On the one hand, Western technology could stimulate economic growth and Western consumer goods could assuage domestic pressures on the regime. On the other hand, increased economic and financial relations with the West could undermine the regime's stability or constrain its options. In addition, relationships with Moscow had to be factored in, as international economic relations affected each country's degree of dependence on the Soviet Union (for the CMEA member states) or its room for manoeuvre (Yugoslavia). We assume each national elite was a heterogeneous group featuring different opinions ranging from reformist to conservative, and in which positions might well have changed over time.

- Which factors explain the eventual failure of these national strategies? We explore the economic and institutional predicaments the socialist regimes had to face and try to assess the interactions between the domestic constraints of a rigid planning system and the multiple, rapid and often unpredictable transformations in the international context. These transformations changed the rules of the game, and the very playing field, in many ways that were hard to gauge or even imagine at the beginning of the decade, thus altering the whole set of equations at the basis of the socialist strategies. As we progressed in this work, we realised that finding out why the strategies failed also entailed an assessment of the socialist elites' efforts at understanding what was going 
wrong, what (if anything) could be adapted on the go, and what could not be salvaged. In short, a new question arose about when and how it became evident that the strategy was failing.

\section{Methodology}

The basic assumption at the root of our project is that there was an emergence of a space for pan-European cooperation that transcended, yet did not obliterate, the Cold War partition. Therefore, our analysis is not of the socialist bloc as such. On the contrary, we aimed precisely at appraising the individual experiences of the socialist regimes in Europe when they were re-conceptualising and re-negotiating their roles in the changing international and continental scenario, their relationships with the Soviet Union and their national senses of being "European". We considered all the European socialist countries except Albania, devoting a chapter to each: the German Democratic Republic, Poland, Hungary, Czechoslovakia, Romania, Bulgaria and Yugoslavia, which was not a member of the CMEA or the Warsaw Pact. By the same logic, we excluded the Soviet Union as the role, self-perception, predicaments and interests of the superpower were quite different from those of the smaller European socialist regimes. Of course, Soviet views and policies do feature in our analysis as key factors affecting national debates, cooperation strategies with the West and ultimately each country's perception of its room for manoeuvre.

We were also dissatisfied with the narrow view of socialist regimes as party-ruled monolithic entities. We intended to open the socialist regimes' "black box" to reveal the more complex and multi-faceted debates that took place within, between and across the elites most involved in the national analysis and decision-making processes. Therefore, we moved beyond a narrow focus on the communist parties' top political leaderships to also analyse the contributions of state machineries, central and investment banks, trade managers, economic experts and academics. In the government apparatus, we specifically considered the ministries and agencies most concerned with relations with the West, usually the Ministry of Foreign Affairs and the Ministry of Foreign Trade. Within their ranks, the staff dispatched abroad (diplomats, trade attachés, ad hoc advisers) also appeared to be particularly active and relevant in the debate. We also focused on those branches of the state that were more directly responsible for the national economic strategy, such as the Central Planning Commission, the Economic Ministry and the Economic Committee of the Council of Ministers. We considered the managerial elite level to be particularly interesting. The officials at the national central banks and investment banks, which are usually overlooked, had an increasing say in the debate as imports from the West fuelled external debt. On their part, the managers of the socialist foreign trade enterprises had a direct stake in the growth of relations with Western Europe and the EEC. We were interested in investigating and appraising the approaches of these agents who negotiated, organised and staffed most of the trans-European exchanges, and their views on the multiple spaces they tried to connect. Finally, experts associated with research institutes, academies and 
universities were key agents in the circulation of ideas among and within socialist states (and beyond). They often had crucial analytical, cognitive and discursive roles, the differentiated impact of which on political elites deserves full appraisal. Of course, the exact composition and weight of the elites involved in the debate varied from country to country, as the country-specific chapters make clear. These variations are also part of the comparative assessment presented in Chapter 10.

We identified the years between 1969 and the early 1980s as the crucial chronological span due to three interrelated processes that had profound influences on the matter under scrutiny: long-lasting détente in East-West relations, the socialist countries' inclination to cautiously integrate into the world economy, and the EEC's enlargement, deepening and self-assertion as an international actor. Therefore, 1969 is the starting point for all the chapters, due to three fundamental settings that emerged at the time. First, the Warsaw Pact countries' military suppression of the Prague Spring reform (with the sole opposition of Romania) set the limits that the Soviets would tolerate in terms of (political) reforms in any of these countries. The lesson of the invasion would be omnipresent in the considerations of most of the European socialist regimes, including non-aligned Yugoslavia, affecting their policies towards Western Europe and the EEC in various ways. It induced varying degrees of restraint but it also stimulated more autonomous and nationalistic attitudes (most noticeably in Romania) or openly strengthened the urge to reach out to the West (Yugoslavia). Second, in 1969 détente with the East became a mainstream Western policy, as the US under President Richard Nixon and the Federal Republic of Germany led by Chancellor Willy Brandt fully embraced a relaxation of tensions and cooperation with the Soviet Union and its allies. While trade relations had already existed in previous years, West Germany's new Ostpolitik allowed for a systematic development of economic exchanges, opening a wide avenue for the modernisation efforts of the socialist economies. Third, at the 1969 EEC summit at The Hague, the six member states agreed to proceed with the completion and deepening of their integration process and with negotiations for the accession of Ireland, Denmark and, most importantly, the UK. These decisions signalled to the socialist countries that far from being in crisis the EEC was actually growing stronger and larger, taking on an economic role and a weight that could no longer be disregarded.

By contrast, identifying a precise common endpoint year for our national cases would have been artificial. We did not intend to go beyond the mid-1980s, since the arrival of Mikhail Gorbachev with his radical views on international relations heralded the full acceptance of a pan-European space for cooperation and rapidly diminished the political constraints of the USSR on its allies, thus inaugurating profoundly different dynamics. The main benchmark for our research goal was the moment when it became apparent to the socialist regime elites that their strategy of import-led growth and integration in the world economy was failing, and that their agency in shaping relations with the West, the EEC and global markets was very limited. This took place at different moments in the early 1980s, and each chapter details these national specificities. 
Finally, a word about terminology. We refer to the countries under scrutiny as socialist rather than communist. Our guiding principle has been to respect the definition the historical actors themselves adopted at the time according to their Marxist-Leninist lexicon. Communism was conceived as the final stage of the path that these regimes had embarked upon, yet they collapsed way before reaching the promised land. In the 1970s, they described their stages of progress on the path to communism with varying terms: advanced socialism, developing socialism (in the case of Romania) or self-management socialism (in the unique instance of Yugoslavia). In a research project that foregrounds these regimes' agency and self-understanding and which is focused on their economies, the term 'communist' - inevitably also loaded with Western Cold War connotations - is appropriately used when referring to the party and its ideology. We also trust our readers not to be perplexed or misled by the formula 'European socialist countries' since their difference and distance from the social-democratic regimes of Western Europe (like Sweden) is all too apparent.

\section{Organisation of the book}

Our research effort was closely coordinated and collective, and this book tries to achieve coherence and thematic unity by means of shared research questions and a shared format and structure. Two overview chapters explore the overall context, the shared settings and the historiographical debates in which the country-specific analyses are embedded. Chapter 1 provides a critical overview of the international economic transformations and turning points, such as the two 'oil shocks' that altered the trading, financial and conceptual context within which the socialist strategies rose and fell. It contextualises the dynamics of East-West cooperation within the changing paradigms that replaced Keynesian management with global market competition. Chapter 2 focuses on the emerging pan-European space for cooperation. It considers political and economic interactions at the bilateral and multilateral levels (including the CSCE process), the patterns of integration in both the West and the East (EEC and CMEA) together with their interplay, and the impact of the European Economic Community's policies on the socialist countries.

The national case contributions (Chapters 3 to 9) follow a common format in order to allow the single cases to speak to one another effectively and facilitate the identification and discussion of both common patterns and national specificities. Each chapter illustrates and contextualises the origins, development and results of the country's national economic strategy with regard to East-West cooperation and relations with the EEC. More specifically, each chapter presents the country's economic specificities, its international commercial and financial strategy, the goals, assumptions and expectations of its elites, and the latter's assessment of the EEC's impact on the economy. Thus, each chapter brings to the fore the actors and internal dynamics in the decision-making process, with insights into the representation of the strategy to the domestic public. Particular attention is given to the elites' appraisals of the strategies of the other socialist countries, their 
relations with CMEA politics and policies and their perceptions of the country's room for manoeuvre vis-à-vis the Soviet Union. To varying degrees, the chapters examine the implementation of the strategy, its shortcomings and its adjustments in response to domestic and international factors. Each chapter concludes with an overall assessment of the outcomes of the strategy and a brief comparison of the national trajectory with the other socialist experiments.

Chapter 10 presents the overall results of the project in relation to its research questions, outlines the main comparative findings and highlights this study's contribution to a diverse range of historiographical debates.

\section{Notes}

1 Bange and Niedhart, Helsinki 1975 and the transformation of Europe; Romano, From Détente in Europe; Villaume and Westad, Perforating the Iron Curtain; Pons and Romero, "Europe between the superpowers"; Autio-Sarasmo and Miklóssy, Reassessing Cold War Europe.

2 Romano, From Détente in Europe; Zaccaria, The EEC's Yugoslav policy; Romano, "The EC and the socialist world."

3 Steiner, "The decline of Soviet-type economies."

4 Steiner, "The decline of Soviet-type economies," 219.

5 Kotkin, "The kiss of debt."

6 Kopstein, The politics of economic decline, 46.

7 Bunce, Subversive institutions, 37.

8 Berend, "What is Central and Eastern Europe?"; Kotkin and Gross, Uncivil society; Romero, Storia della guerra fredda.

9 Bockman, Markets in the name of socialism; Steiner, "The globalisation process and the Eastern bloc countries"; Sanchez-Sibony, Red globalization; Kansikas, Socialist countries face the European Community; Fürst, Pons and Selden, Endgames?; Pula, Globalization under and after socialism; Mark et al., 1989: a global history of Eastern Europe.

10 Bideleux and Taylor, European integration and disintegration; Berend, From the Soviet bloc to the European Union; Bideleux and Jeffries, A history of Eastern Europe; Guida, L'altra metà del continente; Berend, From the Soviet bloc to the European Union; Ther, Europe since 1989.

11 On the former, see Zubok, "The Soviet Union"; Rey, "Le retour à l'Europe?"; English, "Soviet elites and European integration". On the latter, Jajesniak-Quast, "Reaktionen auf die Westeuropäische"; Obadic, "A troubled relationship."

\section{Bibliography}

Autio-Sarasmo, Sari and Katalin Miklossy, eds. Reassessing Cold War Europe. London: Routledge, 2011.

Bange, Oliver and Gottfried Niedhart, eds. Helsinki 1975 and the transformation of Europe. Oxford: Berghahn Books, 2008.

Berend, Ivan T. "What is Central and Eastern Europe?" European Journal of Social Theory 8:4 (2005): 401-16.

Berend, Ivan T. From the Soviet bloc to the European Union: the economic and social transformation of Central and Eastern Europe since 1973. Cambridge: Cambridge University Press, 2009. 
Bideleux, Robert and Ian Jeffries. A history of Eastern Europe: crisis and change. London and New York: Routledge, 1998.

Bideleux, Robert and Richard Taylor, eds. European integration and disintegration: East and West. London and New York: Routledge, 1996.

Bockman, Johanna. Markets in the name of socialism: the left-wing origins of neoliberalism. Stanford: Stanford University Press, 2011.

Bunce, Valerie. Subversive institutions: the design and destruction of socialism and the state. New York: Cambridge University Press, 1999.

English, Robert. "Soviet elites and European integration: from Stalin to Gorbachev." European Review of History 21:2 (2014): 219-33.

Fürst, Juliane, Silvio Pons and Mark Selden, eds. The Cambridge history of communism, vol. 3, Endgames? Late communism in global perspective, 1968 to the present. Cambridge: Cambridge University Press, 2017.

Guida, Francesco, ed. L'altra metà del continente. L'Europa centro-orientale dalla formazione degli Stati nazionali all'integrazione europea. Padova: Cedam, 2003.

Jajesniak-Quast, Dagmara. "Reaktionen auf die Westeuropäische Wirtschaftsintegration in Ostmitteleuropa: Die Tschechoslowakei und Polen in den fünfziger bis zu den siebziger Jahren.” Journal of European Integration History 13:2 (2007): 69-84.

Kansikas, Suvi. Socialist countries face the European Community: Soviet-bloc controversies over East-West trade. Bruxelles: Peter Lang, 2014.

Kopstein, Jeffrey. The politics of economic decline in East Germany, 1945-1989. Chapel Hill: University of North Carolina Press, 1997.

Kotkin, Stephen. "The kiss of debt." In The shock of the global: the 1970s in perspective, edited by Niall Ferguson, Charles S. Maier, Erez Manela and Daniel Sargent, 80-92. Cambridge, MA: Belknap Press of Harvard University Press, 2010.

Kotkin, Stephen and Jan Tomasz Gross. Uncivil society: 1989 and the implosion of the communist establishment. New York: Modern Library, 2009.

Mark, James, Jacob Bogdan, Tobias Rupprecht and Ljubica Spaskovska. 1989: a global history of Eastern Europe. Cambridge: Cambridge University Press, 2019.

Naimark, Norman, Silvio Pons and Sophie Quinn-Judge, eds. The Cambridge history of communism, vol. 2, The socialist camp and world power 1941-1960s. Cambridge: Cambridge University Press, 2017.

Obadic, Ivan. "A troubled relationship: Yugoslavia and the European Economic Community in détente." European Review of History 21:2 (2014): 329-48.

Pons, Silvio and Federico Romero, eds. "Europe between the superpowers, 1968-1981." In Europe in the international arena during the 1970s: entering a different world, edited by Antonio Varsori and Guia Migani, 85-97. Bruxelles: Peter Lang, 2011.

Pons, Silvio and Stephen A. Smith, eds. The Cambridge history of communism, vol. 1, World revolution and socialist in one country 1917-1941. Cambridge: Cambridge University Press, 2017.

Pula, Besnik. Globalization under and after socialism: the evolution of transnational capital in Central and Eastern Europe. Stanford: Stanford University Press, 2018.

Rey, Marie-Pierre. "Le retour à l'Europe? Les décideurs soviétiques face à l'intégration ouesteuropéenne, 1957-1991.” Journal of European Integration History 11:1 (2005): 7-28.

Romano, Angela. From détente in Europe to European Détente: how the West shaped the Helsinki CSCE. Brussels: Peter Lang, 2009.

Romano, Angela. "The EC and the socialist world: the ascent of a key player in Cold War Europe." In Europe's Cold War relations: the EC towards a global role, edited by 


\section{Angela Romano and Federico Romero}

Ulrich Krotz, Kiran Klaus Patel and Federico Romero, 51-69. New York: Bloomsbury Academic, 2019.

Romero, Federico. Storia della guerra fredda: l'ultimo conflitto per l'Europa. Torino: Einaudi, 2009.

Sanchez-Sibony, Oscar. Red globalization: the political economy of the Soviet Cold War from Stalin to Khrushchev. New York: Cambridge University Press, 2014.

Steiner, André. "The globalisation process and the Eastern bloc countries in the 1970s and 1980s." European Review of History: Revue europeenne d'histoire 21:2 (2014): 165-181.

Steiner, André. "The decline of Soviet-type economies." In The Cambridge history of communism, vol. 3, Endgames? Late communism in global perspective, 1968 to the present, edited by Juliane Fürst, Silvio Pons and Mark Selden, 178-202. Cambridge: Cambridge University Press, 2017.

Ther, Philipp. Europe since 1989: a history. Princeton: Princeton University Press, 2016.

Villaume, Poul and Odd Arne Westad, eds. Perforating the Iron Curtain: European détente, transatlantic relations and the Cold War, 1965-1985. Copenhagen: Museum Tusculanum, 2010.

Zaccaria, Benedetto. The EEC's Yugoslav policy in Cold War Europe, 1968-1980. London: Palgrave Macmillan, 2016.

Zubok, Vladislav. "The Soviet Union and European integration from Stalin to Gorbachev." Journal of European Integration History 2:1 (1996): 85-98. 